\title{
Validitas dan Reliabilitas Instrumen Penilaian Kemampuan Berpikir Tingkat Tinggi tentang Materi Hereditas untuk Peserta Didik SMA/MA
}

\author{
Nining Purnama Dewi ${ }^{1)}$, Yosi Laila Rahmi ${ }^{2)}$ Heffi Alberida ${ }^{3)}$ Rahmawati, ${ }^{4)}$ \\ ${ }^{1)}$ Jurusan Biologi, FMIPA, Universitas Negeri Padang \\ Keterangan Penulis ${ }^{2)}$ \\ yosibio@fmipa.unp.ac.id
}

\begin{abstract}
Implementation of 2013 Curriculum which is able to form students who have the ability to think at a high level as the demands of the times. One effort to develop students' higher-order thinking skills is to use appropriate assessments so that students can get used to work on higher-order thinking skills. This study aims to produce an instrument for assessing high-order thinking skills about heredity material for students of class XII SMA / MA that are valid and reliable. This study uses a 4-D models development model consisting of the stages of define, design, develop, and disseminate. The subjects of this study were 3 validators, 2 biology subject teachers and 33 students of class XII MIPA 3 at SMAN 7 Padang. The data collection instrument was in the form of a validity questionnaire filled out by biology lecturers at UNP and biology subject teachers at SMAN 7 Padang. Data analysis using the ANATES 4.09 application. Based on the results of the data analysis instrument for the assessment of high-order thinking skills that have been tested, the results obtained are in the form of an instrument for assessing high-order thinking skills about heredity material for students of class XII SMA / MA that are logically very valid with a value of $93.14 \%$, high of empirical with a value of $74 \%$, and very reliable with a value of 8,4 . Which can be used by teachers to measure and activate students' of higher-order thinking skills.
\end{abstract}

Keywords : Instrument, Higher Order Thinking Skills, Heredity

(i) his is an open access article distributed under the Creative Commons 4.0 Attribution License, which permits unrestricted use, distribution, and reproduction in any medium, provided the original work is properly cited. $\odot 2018$ by author and Universitas Negeri Padang.

\section{PENDAHULUAN}

Sistem pendidikan di Indonesia telah menerapkan Kurikulum 2013 untuk semua jenjang pendidikannya. Pada Kurikulum 2013 telah dilakukan penyempurnaan terhadap standar isi yaitu dengan mengurangi materi yang tidak relevan serta memperkaya materi dengan kebutuhan peserta didik untuk berpikir kritis dan analisis sesuai dengan standar internasional. Penyempurnaan lainnya juga dilakukan pada standar penilaian, dengan mengadaptasi secara bertahap model-model penilaian internasional. Penilaian hasil belajar diharapkan mampu untuk meningkatkan kemampuan berpikir tingkat tinggi atau higher order thinking skills (HOTS) peserta didik, karena berpikir tingkat tinggi dapat mendorong peserta didik untuk berpikir secara luas dan mendalam tentang materi pembelajaran (Kemendikbud, 2017).
Hal ini sejalan dengan pendapat Jamaluddin (2018) pentingnya pengembangan kemampuan berpikir peserta didik bertujuan untuk menghasilkan sumber daya manusia (SDM) yang mampu bertahan di tengah persaingan global dimasa kini dan masa depan yang semakin rumit dan kompleks dalam berbagai aspek kehidupan masyarakat. Kemampuan peserta didik dapat diamati melalui aspek kognitif dari peserta didik itu sendiri. Menurut Amelia (2016) kemampuan kognitif peserta didik dapat diketahui dari hasil pengujian. Pengujian dapat dilakukan menggunakan instrumen penilaian berupa tes maupun non tes.

Penggunaan instrumen penilaian yang baik akan menghasilkan data yang baik. Guru dapat mengetahui kemampuan siswa dengan tepat jika instrumen penilaian yang digunakan baik. Arikunto (2016) menyatakan instrumen dapat dikatakan baik apabila memenuhi lima 
persyaratan, yaitu: validitas, reliabilitas, objektivitas, praktikalitas dan ekonomis. Berdasarkan pendapat Arikunto di atas, kriteria minimal suatu instrumen penilaian yang baik adalah instrumen tersebut harus valid dan reliabel, memiliki daya pembeda, tingkat kesukaran yang bervariasi dan soal pengecoh juga baik. Asesmen pendidikan akan membawa makna yang berarti dalam menyediakan informasi yang tepat dan akurat bagi pengambil kebijakan, apabila instrumen yang digunakan memenuhi kriteria sebagai instrumen yang baik dan benar, diadministrasikan secara baik dan diolah secara objektif berdasarkan kriteria yang tepat dan seharusnya. Suatu instrumen dikatakan valid atau mempunyai validitas yang tinggi apabila mampu mengukur apa yang ingin diukur (Yusuf, 2015).

Validitas suatu instrumen menurut Depdiknas (2017) didasarkan pada empat aspek yaitu.

1) Aspek materi, yaitu materi yang dikembangkan harus sesuai dengan tuntutan Kompetensi Dasar dan indikator.

2) Aspek konstruksi, yaitu soal dirumuskan secara singkat, jelas dan tegas serta berkaitan dengan materi yang ditanyakan.

3) Aspek bahasa, setiap soal harus menggunakan bahasa yang sesuai dengan kaidah bahasa Indonesia dan pilihan jawaban soal tidak mengulang kata atau kelompok kata yang sama.

4) Aspek kemampuan berpikir tingkat tinggi, soal yang dibuat terdiri dari tingkat kognitif $\mathrm{C}^{4}-\mathrm{C}^{6}$.

Instrumen penilaian yang dapat digunakan untuk mengetahui tingkat kognitif peserta didik yaitu melalui tes tertulis. Tes tertulis sekaligus sebagai sarana untuk mengukur kemampuan berpikir tingkat tinggi peseta didik. Keterampilan berpikir tingkat tinggi terjadi ketika seseorang menggabungkan informasi baru dengan informasi yang sudah ia ketahui dan menyampaikannnya untuk permasalahan yang akan dipecahkan (Wardany, 2015). Krathwohl (2002) menyatakan indikator untuk mengukur kemampuan berpikir tingkat tinggi meliputi kemampuan menganalisis $\left(\mathrm{C}_{4}\right)$, yaitu memisahkan konsep kedalam beberapa konsep secara utuh, mengevaluasi $\left(\mathrm{C}_{5}\right)$ yaitu kemampuan meletakkan derajat sesuatu berdasarkan norma, kriteria atau patokan tertentu, dan mencipta $\left(\mathrm{C}_{6}\right)$ yaitu kemampuan memadukan unsur-unsur menjadi sesuatu bentuk baru yang utuh dan luas, atau membuat sesuatu yang orisinil. Keterampilan berpikir tingkat tinggi meliputi kemampuan untuk memecahkan masalah (problem solving), keterampilan berpikir kritis (critical thinking), berpikir kreatif (creative thinking), kemampuan berargumen (reasoning), dan kemampuan mengambil keputusan (decision making).

Selain itu menurut Widana (2017) HOTS tidak hanya mengukur dimensi faktual, konseptual atau prosedural, namun pada umumnya mengukur dimensi metakognitif. Dimensi metakognitif menggambarkan kemampuan menghubungkan beberapa konsep yang berbeda, menginterpretasikan, memecahkan masalah, memilih strategi pemecahan masalah, menemukan metode baru, memberikan argumen serta mengambil keputusan yang tepat. Kreativitas menyelesaikan permasalahan dalam HOTS, sebagai berikut.

1) Kemampuan menyelesaikan permasalahan yang tidak familiar

2) Kemampuan mengevaluasi strategi yang digunakan untuk menyelesaikan

masalah dari berbagai sudut pandang yang berbeda

3) Menemukan model-model penyelesaian baru yang berbeda dengan cara-cara sebelumnya (Kemendikbud, 2019).

Studi internasional yang mengukur kemampuan berpikir tingkat tinggi peserta didik yaitu TIMSS (Trends In Mathematics and Science Study) dan PISA (Programme For International Student Assessment). Indonesia sudah berpartisipasi dalam studi TIMSS sejak tahun 1999, namun capaian peserta didik di Indonesia masih dikategorikan rendah dibandingkan negara lain. Tahun 2015 Indonesia berada pada urutan 44 dari 49 negara yang mengikuti TIMSS dengan perolehan skor 397 dari 500 skor internasional. Dan dari data PISA tahun 2018 menunjukkan bahwa kemampuan peserta didik di Indonesia dalam bidang sains berada pada 
peringkat 69 dengan skor 396 dari 78 negara yang dievaluasi (OECD, 2019). Hal ini menunjukkan bahwa kemampuan berpikir tingkat tinggi peserta didik di Indonesia masih tergolong rendah, sehingga diperlukan upaya untuk peningkatan kemampuan berpikir tingkat tinggi peserta didik.

Peningkatan kemampuan berpikir tingkat tinggi peserta didik dapat dilakukan melalui perubahan sistem dalam pembelajaran dan penilaian. Menurut Suwandi (2009), Burden (2013) insrtrumen penilaian yang mengukur HOTS dapat menggunakan bentuk tes subjektif dan tes objektif. Tes subjektif merupakan bentuk tes esai. Tes esai merupakan suatu bentuk tes uraian dengan menggunakan bahasa sendiri. Dalam tes bentuk esai siswa dituntut untuk berpikir tentang dan mempergunakan apa yang diketahui yang berkenaan dengan pertanyaan yang harus dijawab. Tes objektif merupakan bentuk tes yang terdiri dari tes jawaban benar-salah (truefalse), pilihan ganda (multiple choice), isian (completion), dan perjodohan (matching).

Berdasarkan observasi yang dilakukan oleh peneliti di SMA Negeri 7 Padang, pada tanggal 15 April 2019 peneliti melakukan uji coba soal berpikir tingkat tinggi dan menyebarkan angket pada peserta didik. Dari uji coba soal dan penyebaran angket dapat diketahui bahwa kemampuan berpikir tingkat tinggi peserta didik masih tergolong rendah hal ini dibuktikan dengan nilai rata-rata siswa pada uji coba soal hanya 39,14, sejalan dengan Prasetyani (2016) bahwa nilai siswa pada rentang 21-40 berada pada tingkat kemampuan kurang. Rendahnya kemampuan berpikir tingkat tinggi peserta didik disebabkan oleh beberapa faktor yaitu: (1) peserta didik terbiasa dengan tes tertulis yang sebagian besar memuat pertanyaan yang bersifat hafalan dan masih berada pada ranah kognitif $\mathrm{C}_{1}-\mathrm{C}_{3}$. Hal ini dapat dibuktikan dengan analisis soal penilaian harian $(\mathrm{PH})$ pada materi hereditas yang disusun oleh salah seorang guru biologi di SMAN 7 Padang, yang terdiri dari 10 soal pilihan ganda, dimana soal yang berada pada ranah kognitif $\mathrm{C}_{1}$ sebanyak 2 butir soal, $\mathrm{C}_{2}$ sebanyak 4 butir soal, $\mathrm{C}_{3}$ sebanyak 3 butir soal dan hanya 1 butir soal yang berada pada ranah kognitif $\mathrm{C}_{4}$ dan tidak terdapat soal yang ranah kognitifnya berada pada $\mathrm{C}_{5}$ dan $\mathrm{C}_{6}$. Sementara standar minimal tuntutan kompetensi dasar kurikulum 2013 untuk materi hereditas berada pada ranah kognitif $\mathrm{C}_{4}$ yaitu menganalisis. (2) peserta didik merasa soal kemampuan berpikir tingkat tinggi yang diujikan belum sesuai dengan kemampuan mereka karena kemampuan peserta didik masih terbatas untuk mengerjakan soal yang memiliki gambar, grafik, tabel, atau wacana.

Informasi tentang rendahnya kemampuan berpikir tingkat tinggi peserta didik juga didukung oleh hasil wawancara terhadap salah seorang guru mata pelajaran biologi di SMAN 7 Padang pada hari Rabu tanggal 4 September 2019. Dari hasil wawancara diperoleh informasi guru selalu melaksanakan evaluasi setelah proses pembelajaran. Evaluasi yang dilakukan berupa evaluasi tertulis dalam bentuk objektif dan esai terstruktur. Soal yang diberikan bervariasi dan tingkatan terendah berada pada ranah kognitif $\mathrm{C}_{2}$. Walaupun guru sudah mengembangkan soal berpikir tingkat tinggi namun belum maksimal, karena dalam penilaian harian hanya terdapat paling banyak 3 soal yang termasuk soal berpikir tingkat tinggi. Guru memiliki beberapa kendala untuk menerapkan dan membuat soal kemampuan berpikir tinggi. Beberapa kendala yang dimiliki guru yaitu: (1) guru terkendala dalam memikirkan narasi soal yang akan dianalisa peserta didik, terutama dalam memasukkan fakta kontekstual atau kekinian pada narasi soal. (2) siswa terbatas dalam membaca narasi soal dan menganalisa soal yang memuat data berupa grafik dan gambar. Hal ini sejalan dengan Puspita dkk (2019), Armiati dkk (2020) untuk mengembangkan kemampuan berpikir tingkat tinggi peserta didik dipengaruhi oleh persepsi dan profesionalisme guru dalam mengembangkan instrumen kemampuan berpikir tingkat tinggi.

Salah satu upaya untuk mengembangkan kemampuan berpikir tingkat tinggi menurut Rahmi dan Alberida (2017) adalah dengan menggunakan asesmen yang tepat. Jadi untuk itu perlu dikembangkan intrumen 
penilaian kemampuan berpikir tingkat tinggi yang valid dan reliabel agar dapat dijadikan pedoman oleh guru dalam melakukan penilaian selanjutnya, sehingga juga dapat melatih peserta didik untuk berpikir tingkat tinggi sesuai tuntutan kurikulum 2013.

Pada artikel ini, peneliti telah mengembangkan instrumen penilaian kemampuan berpikir tingkat tinggi tentang meteri hereditas. Materi hereditas merupakan KD 3.7 materi kelas XII semester ganjil yang kata kerja operasionalnya sudah berada pada $\mathrm{C}_{4}$, yaitu menganalisis pola-pola hereditas pada manusia berdasarkan studi kasus dalam berbagai aspek kehidupan. Adapun tujuan dari penelitian ini adalah untuk menghasilkan instrumen penilaian kemampuan berpikir tingkat tinggi tentang materi hereditas untuk peserta didik kelas XII SMA/MA yang valid secara logis dan empiris dan reliabel.

\section{METODE PENELITIAN}

Jenis penelitian ini adalah penelitian pengembangan (development research). Penelitian ini bertujuan untuk menghasilkan produk berupa instrumen penilaian kemampuan berpikir tingkat tinggi tentang materi hereditas untuk peserta didik kelas XII SMA/MA yang praktis dengan menggunakan model pengembangan berupa 4-D (four-D models). Tahapan four-D models yaitu: pendefinisian (define), perancangan (design), pengembangan (develop), dan penyebaran (desseminate). Akan tetapi karena keterbatasan waktu dan biaya peneliti tidak melakukan tahap desseminate.

Subjek penelitian ini terdiri dari validator yaitu dua orang dosen Jurusan Biologi Universitas Negeri Padang dan satu orang guru mata pelajaran biologi di SMAN 7 Padang, dan subjek uji coba adalah dua orang guru mata pelajaran biologi di SMAN 7 Padang dan 33 orang peserta didik kelas XII MIPA 3 di SMAN 7 Padang. Objek penelitian ini adalah instrumen penilaian kemampuan berpikir tingkat tinggi tentang materi hereditas untuk peserta didik kelas XII SMA/MA berupa 50 butir soal. Penelitian ini dilakukan di Universitas Negeri
Padang (UNP) dan SMA Negeri 7 Padang. Produk yang dihasilkan berupa instrumen penilaian kemampuan berpikir tingkat tinggi tentang materi hereditas untuk peserta didik kelas XII SMA/MA yang dilakukan pada tanggal 15 April 2019 sampai 7 Maret 2020. Instrumen pengumpulan data bersifat kuantitatif berupa angket validasi.

\section{A. Hasil Penelitian}

\section{HASIL DAN PEMBAHASAN}

1. Validitas Logis Instrumen Penilaian Kemampuan Berpikir Tingkat Tinggi

Validitas logis pada instrumen penilaian kemampuan berpikir tingkat tinggi ini bertujuan untuk membuktikan kevalidan instrumen penilaian yang dikembangkan. Validitas logis ini dilakukan oleh dua orang dosen biologi FMIPA UNP dan satu orang guru mata pelajaran biologi di SMAN 7 Padang, dengan menggunakan angket validasi. Selama proses validasi terdapat beberapa saran dari validator yang dijadikan pertimbangan dalam memperbaiki instrumen penilaian kemampuan berpikir tingkat tinggi pada materi hereditas. Perbaikan yang disarankan oleh validator melalui angket validasi diperbaiki sesuai dengan saran yang diberikan yang dapat dilihat pada Tabel 1 .

Tabel 1. Saran Dari Validator Terhadap Instrumen Penilaian Kemampuan Berpikir Tingkat Tinggi Tentang Materi Hereditas

\begin{tabular}{|c|c|c|}
\hline Validator & \multicolumn{2}{|l|}{ Saran } \\
\hline \multirow[t]{4}{*}{1} & \multicolumn{2}{|c|}{$\begin{array}{l}\text { Revisi soal-soal yang masih berada pada } \\
\text { ranah kognitif C3 }\end{array}$} \\
\hline & \multicolumn{2}{|c|}{\begin{tabular}{|l} 
Seorang laki-laki penderita Dentinogenesis imperfecta \\
menikah dengan seorang wanita normal, persentase \\
kemungkinan keturunan penderita Dentinogenesis \\
imperfecta yang lahir adalah... \\
A. $0 \%$ \\
B. $25 \%$ \\
C. $50 \%$ \\
D. $75 \%$ \\
E. $100 \%$
\end{tabular}} \\
\hline & \multicolumn{2}{|l|}{ Perbaiki estetika option } \\
\hline & 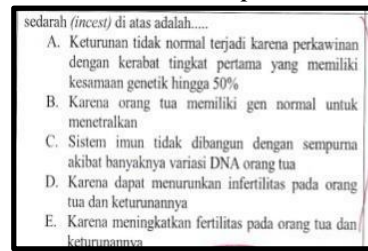 & $\begin{array}{l}\text { Perhativan } \\
\text { estetive } \\
\text { option (uth semont) }\end{array}$ \\
\hline
\end{tabular}




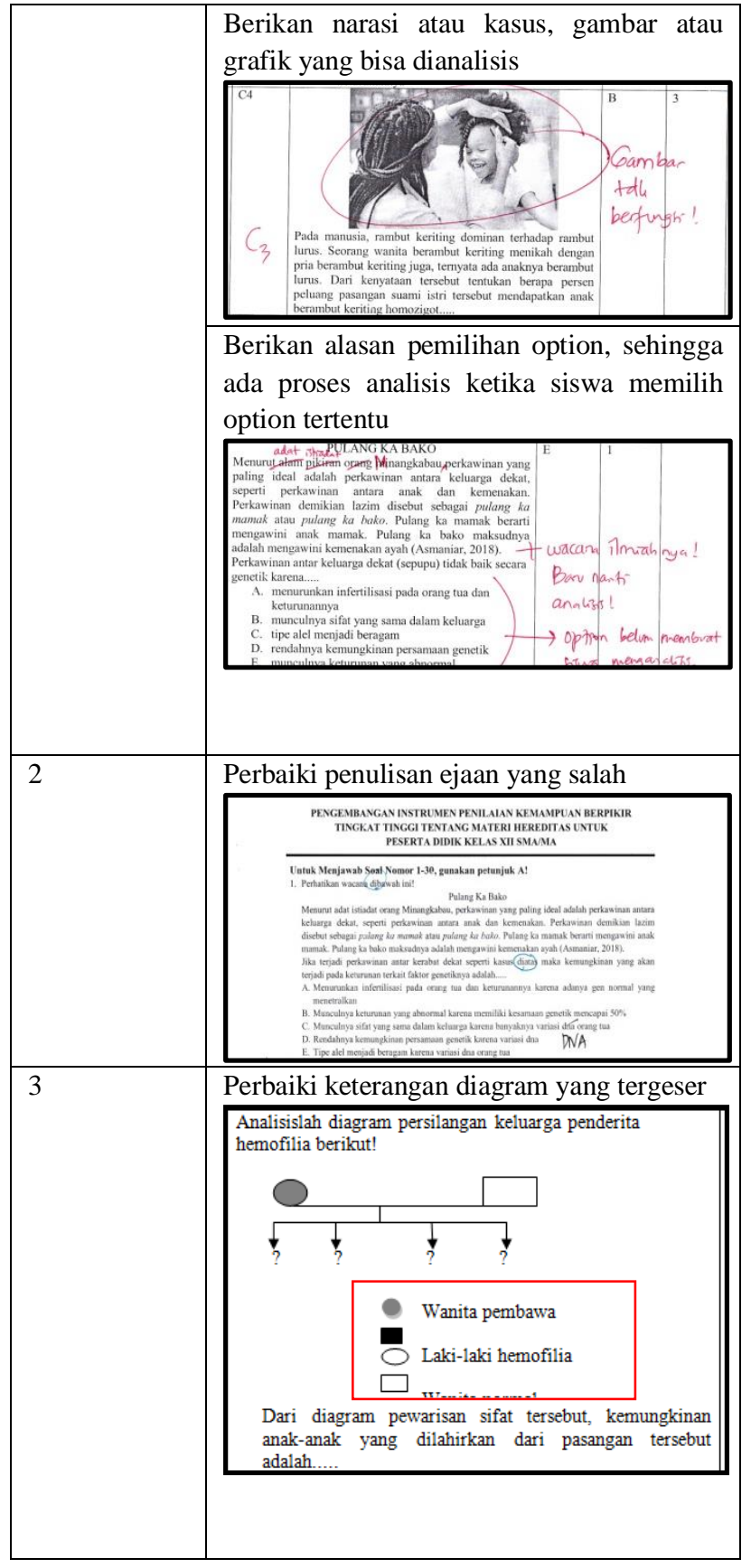

Keterangan validator:

1. Rahmawati D, M.Pd.

2. Drs. Ristiono, M.Pd.

3. Ratnawita, S.Pd.

Setelah mendapatkan saran dari validator dilakukan revisi terhadap saran yang diberikan validator sebagai bentuk upaya penyempurnaan pengembangan instrumen penilaian kemampuan berpikir tingkat tinggi, kemudian dilakukan analisis terhadap angket validasi yang dapat dilihat pada Tabel 3.
Tabel 2. Hasil Analisis Validitas Logis Instrumen Penilaian Kemampuan Berpikir Tingkat Tinggi

\begin{tabular}{|l|l|c|c|c|}
\hline No & $\begin{array}{l}\text { Komponen } \\
\text { Penilaian }\end{array}$ & $\begin{array}{c}\text { Jumlah } \\
\text { poin }\end{array}$ & $\begin{array}{c}\text { Nilai } \\
\text { validitas }\end{array}$ & $\begin{array}{c}\text { Krite- } \\
\text { ria }\end{array}$ \\
\hline 1. & Materi & 102 & $94,44 \%$ & $\begin{array}{c}\text { Sangat } \\
\text { valid }\end{array}$ \\
\hline 2. & Konstruksi & 100 & $92,59 \%$ & $\begin{array}{c}\text { Sangat } \\
\text { valid }\end{array}$ \\
\hline 3. & Bahasa & 35 & $97,22 \%$ & $\begin{array}{c}\text { Sangat } \\
\text { valid }\end{array}$ \\
\hline 4. & $\begin{array}{l}\text { Berpikir } \\
\text { tingkat ting- } \\
\text { gi }\end{array}$ & 53 & $88,33 \%$ & Valid \\
\hline \multicolumn{2}{|l|}{ Jumlah total nilai validitas } & $372,58 \%$ & \\
\hline \multicolumn{2}{|l|}{ Rata-rata nilai validitas } & $93,14 \%$ & $\begin{array}{c}\text { Sangat } \\
\text { Valid }\end{array}$ \\
\hline
\end{tabular}

Berdasarkan hasil validasi pada Tabel 2, dapat disimpulkan bahwa persyaratan untuk memenuhi kriteria kevalidan instrumen penilaian kemampuan berpikir tingkat tinggi telah terpenuhi. Hal ini dilihat dari rata-rata keseluruhan untuk nilai validasi instrumen penilaian kemampuan berpikir tingkat tinggi adalah 93,14\% (sangat valid). Hasil validitas ini menunjukkan bahwa instrumen penilaian kemampuan berpikir tingkat tinggi yang dikembangkan oleh penulis valid, baik dari segi materi, konstruksi, bahasa, dan berpikir tingkat tinggi.

2. Validitas Empiris Instrumen Penilaian Kemampuan Berpikir Tingkat Tinggi

Nilai validitas empiris instrumen penilaian didapatkan dengan melakukan analisis butir soal. Analisis butir soal dilakukan setelah melakukan uji instrumen penilaian kemampuan berpikir tingkat tinggi yang dilakukan pada tanggal 7 Maret 2020 kepada 33 orang peserta didik kelas XII MIPA 3 SMAN 7 Padang. Analisis butir soal dilakukan dengan menggunakan ANATES versi 4.09.

Berdasarkan hasil analisis butir soal, dihasilkan 37 butir soal yang valid dengan persentase $74 \%$ dan 13 butir soal tidak valid dengan persentase $26 \%$. Adapun jumlah soal yang berada pada ranah kognitif $\mathrm{C}_{4}$ sebanyak 30 butir 
soal, $\mathrm{C}_{5}$ sebanyak 6 butir soal, dan $\mathrm{C}_{6}$ sebanyak 1 butir soal yang dideskripsikan dalam diagram pada Gambar 1 berikut.

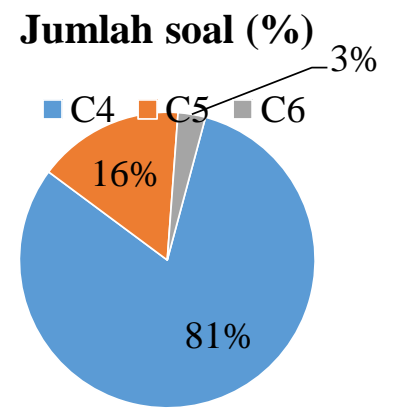

Gambar 1. Diagram Persentase Tingkatan Kognitif Soal Valid

Soal-soal yang valid tersebut sudah mewakili semua indikator pencapaian kompetensi dan melingkup ranah kognitif $\mathrm{C}_{4}-\mathrm{C}_{6}$. Data analisis butir soal dapat dilihat pada Tabel 3 berikut.

Tabel 3. Hasil Analisis Validitas Empiris Instrumen Penilaian Kemampuan Berpikir Tingkat Tinggi

\begin{tabular}{|c|c|c|c|c|c|}
\hline \multicolumn{7}{|c|}{$\begin{array}{c}\text { Validitas Empiris } \\
\text { (Multiple } \\
\text { Choice })\end{array}$} & $\begin{array}{c}\text { Analisis Hub- } \\
\text { ungan Sebab } \\
\text { Akibat }\end{array}$ & \multicolumn{2}{c|}{$\begin{array}{c}\text { Asosiasi } \\
\text { Ailihan Ganda }\end{array}$} & \multicolumn{2}{c|}{} \\
\hline Valid & Tidak & Valid & Tidak & Valid & Tidak \\
& Valid & & Valid & & Valid \\
\hline $\begin{array}{c}\text { 23 soal } \\
(0,313\end{array}$ & 7 soal & 8 soal & 2 soal & 6 soal & 4 soal \\
- & - & - & - & - & - \\
$0,724)$ & $0,247)$ & $0,779)$ & $0,206)$ & $0,701)$ & $0,165)$ \\
\hline
\end{tabular}

3. Reliabilitas Instrumen Penilaian Kemampuan Berpikir Tingkat Tinggi

Reliabilitas instrumen penilaian kemampuan berpikir tingkat tinggi diketahui dari analisis butir soal menggunakan ANATES versi 4.09.

Berdasarkan hasil analisis butir soal, dihasilkan 37 butir soal yang reliabel dengan nilai reliabilitas yang sangat reliabel yaitu 0,84 .

\section{B. Pembahasan}

1. Validitas Logis Instrumen Penilaian Kemampuan Berpikir Tingkat Tinggi

Validitas logis didapatkan dari analisis data angket validasi yang diisi oleh 3 orang validator. Analisis data dari angket validitas instrumen penilaian berpikir tingkat tinggi oleh dosen dan guru didasarkan pada empat aspek yaitu materi, konstruksi, bahasa dan kemampuan berpikir tingkat tinggi. Sugiyono (2012) menyatakan bahwa validitas merupakan derajat ketepatan antara data yang terjadi pada objek penelitian dengan data-data yang sesungguhnya. Hasil analisis data menunjukkan bahwa instrumen penilaian berpikir tingkat tinggi yang dikembangkan dikategorikan sangat valid dengan nilai $93,14 \%$. Nilai dari hasil analisis ini merupakan hasil rata-rata nilai dari keempat aspek tersebut.

Dilihat dari aspek materi didapatkan nilai rata-rata dari ketiga validator sebesar $94,44 \%$ dan dinyatakan valid. Kriteria valid pada instrumen penilaian kemampuan berpikir tingkat tinggi ini menunjukkan bahwa materi yang dikembangkan dapat digunakan untuk mengembangkan kemampuan berpikir tingkat tinggi peserta didik. Materi yang dikembangkan juga sesuai dengan Kurikulum 2013 dan telah sesuai dengan Kompetensi Inti dan Kompetensi Dasar. Hal ini sesuai dengan Depdiknas (2017) menyatakan, bahwa materi yang dikembangkan harus sesuai dengan tuntutan Kompetensi Inti dan Kompetensi Dasar.

Ditinjau dari aspek konstruksi, instrumen penilaian kemampuan berpikir tingkat tinggi ini sudah valid dengan persentase $92,59 \%$. Hal ini menunjukkan bahwa pokok soal dirumuskan dengan jelas, pokok soal dan pilihan jawaban merupakan pernyataan yang diperlukan saja, pokok soal tidak memberi petunjuk kunci jawaban, butir soal tidak tergantung pada jawaban soal sebelumnya, dan pilihan jawaban yang berbentuk angka disusun berdasarkan besar kecilnya angka dan kronologisnya. Hal ini sesuai dengan Depdiknas (2017), bahwa soal harus dirumuskan secara singkat, jelas, dan tegas serta harus berkaitan dengan materi yang ditanyakan. 
Ditinjau dari segi bahasa, instrumen penilaian kemampuan berpikir tingkat tinggi ini sudah valid dengan persentase $97,22 \%$, artinya soal pilihan ganda yang dibuat sudah menggunakan bahasa yang sesuai dengan Bahasa Indonesia yang baik dan komunikatif. Hal ini sesuai dengan Depdiknas (2017) yang mengemukakan bahwa setiap soal harus menggunakan bahasa yang sesuai dengan kaidah Bahasa Indonesia, tidak menggunakan bahasa yang berlaku untuk daerah setempat dan pilihan jawaban soal tidak mengulang kata atau kelompok kata yang sama.

Dilihat dari aspek berpikir tingkat tinggi didapatkan rata-rata sebesar $88,33 \%$ yang mencapai kriteria sangat valid. Hal ini menunjukkan bahwa instrumen penilaian yang digunakan sudah mengukur level kognitif peserta didik yang meliputi menganalisis, mengevaluasi, dan mencipta. Menurut Widiawati, dkk (2018) kemampuan berpikir tingkat tinggi mengedepankan peserta didik untuk menganalisis, mengevaluasi, dan mencipta. Sejalan dengan Krathwohl (2002) dalam A revision of Bloom's Taxonomy, bahwa indikator untuk mengukur kemampuan berpikir tingkat tinggi meliputi menganalisis $\left(\mathrm{C}_{4}\right)$, yaitu memisahkan konsep kedalam beberapa konsep secara utuh, mengevaluasi $\left(\mathrm{C}_{5}\right)$ yaitu kemampuan meletakkan derajat sesuatu berdasarkan norma, kriteria atau patokan tertentu, dan mencipta $\left(\mathrm{C}_{6}\right)$ yaitu kemampuan memadukan unsur-unsur menjadi sesuatu bentuk baru yang utuh dan luas, atau membuat sesuatu yang orisinil.

Dilihat dari keempat aspek didapatkan rata-rata validitas sebesar $93,14 \%$ dari tiga orang validator. Berdasarkan hasil tersebut dapat dikatakan bahwa instrumen penilaian kemampuan berpikir tingkat tinggi untuk peserta didik pada materi hereditas sudah memenuhi validitas logis dan dapat digunakan oleh guru sebagai instrumen penilaian. Namun instrumen ini masih perlu diperbanyak pengembangan soal pada ranah kognitif $\mathrm{C}_{6}$, karena instrumen yang dikembangkan ini masih didominasi oleh ranah kognitif $\mathrm{C}_{4}$. Adapun persentase masing-masing tingkatan yang diperoleh jauh berbeda dengan perencanaan awal penulis, yaitu $\mathrm{C}_{4}=81 \%, \mathrm{C}_{5}=$ $16 \%$, dan $\mathrm{C}_{6}=3 \%$, yang mana ranah kognitif $\mathrm{C}_{4}$ berjumlah 30 butir soal, $\mathrm{C}_{5}$ berjumlah 6 butir dan $\mathrm{C}_{6}$ berjumlah 1 butir setelah melewati proses validasi dan uji coba kepada peserta didik seperti yang dideskripsikan pada Gambar 1.

Secara keseluruhan, instrumen penilaian kemampuan berpikir tingkat tinggi berupa soal pilihan ganda memiliki kriteria valid menurut validitas logis. Hal ini menandakan bahwa instrumen penilaian yang dikembangkan telah memenuhi keempat aspek dalam uji validasi berdasarkan penilaian dari para validator sehingga instrumen penilaian kemampuan berpikir tingkat tinggi ini dapat digunakan dalam penilaian biologi khususnya materi hereditas.Sebelum digunakan harus dilakukan uji validitas secara empiris dan uji praktikalitas, agar instrumen yang digunakan valid dan praktis serta dapat mengembangkan kemampuan berpikir tingkat tinggi peserta didik.

2. Validitas Empiris Instrumen Penilaian Kemampuan Berpikir Tingkat Tinggi

Validitas empiris bertujuan untuk menentukan tingkat kehandalan instrumen penilaian yang dikembangkan. Validitas empiris didapatkan dari hasil analisis butir soal dengan menggunakan ANATES versi 4.09. Soal yang dianalisis sebanyak 50 butir soal pada 33 peserta didik kelas XII MIPA 3 SMAN 7 Padang. Instrumen penilaian dikatakan valid, jika memiliki validitas empiris yang sesuai dengan pengalaman. Berdasarkan analisis soal yang dilakukan, dapat dikatakan bahwa instrumen penilaian kemampuan berpikir tingkat tinggi ini sudah valid berdasarkan validitas empirisnya. Menurut Sukardi (2012) suatu instrumen dikatakan valid apabila instrumen yang digunakan dapat mengukur apa yang hendak diukur. Dari analisis menggunakan ANATES versi 4.09 dihasilkan 37 butir soal yang valid dengan persentase $74 \%$, dan 13 butir soal yang tidak valid dengan persentase $26 \%$ yang tidak valid. Persentase untuk masing-masing tingkatan kognitif soal yaitu, $\mathrm{C}_{4}=81 \%, \mathrm{C}_{5}=16 \%$, dan $\mathrm{C}_{6}=3 \%$. 
3. Reliabilitas Instrumen Penilaian Kemampuan Berpikir Tingkat Tinggi

Reliabilitas merupakan keadaan instrumen yang menunjukkan hasil pengukuran yang reliabel (konsisten). Instrumen yang reliabel yaitu instrumen yang menunjukkan hasil yang relatif sama jika diteskan pada kelompok yang sama pada waktu yang berbeda. Instrumen penilaian kemampuan berpikir tingkat tinggi ini sangat reliabel dengan nilai reliabilitas sebesar 0,84 . Sejalan dengan pendapat Sudjana (2009) bahwa suatu tes dikatakan reliabel (memiliki reliabilitas yang tinggi) bila $\mathrm{r}_{11}$ sama dengan atau lebih besar dari pada 0,70 .

\section{KESIMPULAN}

Instrumen penilaian kemampuan berpikir tingkat tinggi yang dihasilkan memiliki nilai rata-rata validitas logis sebesar 93,14\% dengan kriteria sangat valid, nilai validitas empiris yaitu $74 \%$ dengan persentase untuk masing-masing tingkatan kognitif soal yaitu, $\mathrm{C}_{4}=81 \%, \mathrm{C}_{5}=16 \%$, dan $\mathrm{C}_{6}=3 \%$, dan sangat reliabel dengan nilai reliabilitas 0,84 . Maka dapat disimpulkan bahwa telah dihasilkan instrumen penilaian kemampuan berpikir tingkat tinggi tentang materi hereditas untuk peserta didik kelas XII SMA/MA yang sangat valid secara logis, validitas empiris tinggi dan sangat reliabel yang dapat di gunakan oleh guru untuk mengukur serta melatih kemampuan berpikir tingkat tinggi peserta didik

\section{DAFTAR PUSTAKA}

Amelia, M. A. (2016). Analisis Soal Hasil Tes Belajar High Order Thinking Skills (HOTS) Matematika Materi Pecahan Untuk Kelas 5 Sekolah Dasar. Jurnal Penelitian (Edisi Khusus PGSD) , 123131.

Arikunto, S. (2016). Dasar-Dasar Evaluasi Pendidikan. Jakarta: Bumi Aksara.

Armiati, A., Subhan, M., Nasution, M. L., Al Aziz, S., Rani, M. M., Rifandi, R., \& Harisman, Y. (2020). Profesionalisme Guru dalam Membuat Soal Higher Order Thinking Skills. JNPM (Jurnal Nasional Pendidikan Matematika), 4(1), 75-84.

Burden, B. (2013). Assessment of higher order thinking skills, G. Schraw, DR
Robinson (Eds.), Information Age

Publishing Company (IAP), Charlotte, NC (2011), pp. 418, ISBN: 978-161735-505-9.

Depdiknas. 2017. Panduan Penilaian oleh Pendidik dan Satuan Pendidikan untuk Sekolah Menengah Atas. Jakarta: Direktorat Pembinaan SMA Ditjen Pendidikan Dasar dan Menengah.

Jamaludin, Andayani, Y., \& Purwoko, A. A. (2018). Pelatihan penyusunan Instrumen Keterampilan Berpikir Tingkat Tinggi Bagi Pendidik Mata Pelajaran IPA SMP Di Kota Mataram. Jurnal Pengabdian Magister Pendidikan IPA , 79-85.

Kemendikbud. 2017. Modul Penyusun Soal Higher Order Thinking Skill (HOTS).

Jakarta: Direktorat Pembinaan SMA Ditjen Pendidikan Dasar dan Menengah. Kemendikbud. (2019). Modul Penyusunan Soal Higher Order Thinking Skills (HOTS). Jakarta : Direktorat Pembinaan SMA Ditjen Pendidikan Dasar dan Menengah. Krathwohl, D. (2002). A Revisions of Bloom's taxonomy. Theory into practice,212218.

OECD. (2019). Contry Note Result from PISA 2018. Dipetik desember12, 2019, dari http://www.bps.go.id/-

linktabledinamis/view/id/1054

Prasetyani, E. Y. (2016). Kemampuan Berpikir Tingkat Tinggi Siswa Kelas XI Dalam Pembelajaran Trigonometri Berbasis Masalah. Jurnal Gantang Pendidikan Matematika FKIP - UMRAH , Vol. 1 No. 1.

Puspita, V., Maielfi, D., Mulyati, A., \& Rifandi, R. (2019, October). TEACH-

ERS'PERCEPTION OF HIGH ORDER THINKING SKILLS IN THEMATIC INTEGRATED LEARNING. In Proceeding ASEAN Youth Conference.

Rahmi, Y. L., \& Alberida, H. (2017). Improving students' higher order thinking skills through portfolio assessment on biology curriculum and textbook analysis course. Bioeducation Journal, l(1), 22-33. 
Sudjana, N. (2009). Penilaian Proses Hasil Belajar Mengajar. Bandung: Remaja Rosdakarya.

Sugiyono. 2012. Metode Penelitian Pendidikan Pendekatan Kuantitatif, Kualitatif dan $R \& D$. Bandung: Alfabeta.

Sukardi. 2012. Evaluasi Pendidikan Prinsip dan Operasionalnya. Jakarta: Bumi Aksara.

Suwandi. (2009). Model Asesmen dalam Pembelajaran . Surakarta: Mata Padi Presindo.

Wardany, K., Sajidan, \& Ramli, M. (2015). Penyusunan Instrumen Tes Highher Order Thinking Skills Pada Materi Ekosistem SMA Kelas X. Seminar Nasional XII Pendidikan Biologi FKIP UNS , 538-543.

Widana, W. 2017. Modul Penyusunan Soal Higher Order Thinking Skills (HOTS).

Jakarta: direktorat Pembinaan SMA Direktorat Jenderal Pendidikan Dasar dan Menengah Departemen Pendidikan dan Kebudayaan.

Widiawati, L., S. Joyoatmojo, dan Sudiyanto. 2018. Higher Order Thinking Skills pada Pembelajaran Abad 21. Prosiding Seminar Nasional Hasil Penelitian Pendidikan dan Pembelajaran STKIP PGRI Jombang, Vol.4 No.1, Hal: 295-301.

Yusuf, A. M. 2015. Asesmen dan Evaluasi Pendidikan: Pilar Penyedia Informasi dan Kegiatan Pengendalian Mutu Pendidikan. Jakarta: Prenada media Group 